\title{
VERTOON DIE CORPUS IURIS CIVILIS KENMERKE VAN 'N ABSTRAKTE STELSEL VAN EIENDOMSOORDRAG?
}

\section{ISSN 1727-3781}

2007 VOLUME 3 


\section{VERTOON DIE CORPUS IURIS CIVILIS KENMERKE VAN 'N ABSTRAKTE STELSEL VAN EIENDOMSOORDRAG?}

\section{PJW Schutte*}

\section{$1 \quad$ Inleiding}

Dit word algemeen aanvaar dat 'n abstrakte stelsel van eiendomsoordrag in die Suid-Afrikaanse reg toegepas word. Kenmerkend van 'n abstrakte stelsel is dat die verskillende regshandelinge wat by die oordragsproses betrokke is, naamlik die verbintenisskeppende ooreenkoms, lewering (of registrasie in geval van onroerende goed) en die saaklike ooreenkoms van mekaar geabstraheer is. ${ }^{1}$ Die saaklike ooreenkoms is 'n ooreenkoms tussen die vervreemder en verkryger dat eiendomsreg deur lewering oorgedra word. Dit bestaan dus slegs uit die wedersydse bedoeling om eiendomsreg oor te dra en te ontvang, welke bedoeling 'n selfstandige bestaan voer onafhanklik van die verbintenisskeppende ooreenkoms, waar die bedoeling primêr is om verbintenisse tot stand te bring. Daar kan dus gesê word dat die saaklike ooreenkoms inhoudelik abstrak is. Die ooreenkoms is ook uitwendig abstrak. Daarmee word bedoel dat nietigheid van die verbintenisskeppende ooreenkoms nie noodwendig ook die geldigheid van die saaklike ooreenkoms affekteer nie, omdat dit aan sy eie geldigheidsvereistes moet voldoen. Met ander woorde, eiendomsreg kan op die verkryger oorgaan selfs al is die verbintenisskeppende ooreenkoms nietig. ' $n$ Abstrakte stelsel word dus daardeur gekenmerk (1) dat die wedersydse bedoeling om eiendomsreg oor te dra en te ontvang as 'n selfstandige saaklike ooreenkoms gekonstrueer word wat van die bedoeling by die verbintenisskeppende ooreenkoms onderskei moet word en (2) dat die saaklike ooreenkoms

* BA, B Juris, LL B, LL D, Senior Lektor, Fakulteit Regte, Noordwes-Universiteit (Potchefstroomkampus).

1 Commissioner of Customs and Excise $v$ Randles, Brothers and Hudson 1941 AD 369; AirKell h/a Merkel Motors v Bodenstein 19803 SA 917 (A); Krapohl v Oranje Koöperasie 19903 SA 848 (A); Bank Windhoek v Rajie 19941 SA 115 (A) 141 D-E en 144 H; Concor Construction v Santambank 19933 SA 930 (A); Cape Explosive Works v Denel 20013 SA 569 (HHA) 577-578; Dryer v AXZS Industries 2005 JOL 15566 (SCA). 
aan sy eie geldigheidsvereistes moet voldoen en nie deur gebreke in die verbintenisskeppende ooreenkoms beïnvloed word nie.

Dit word algemeen aanvaar dat die abstrakte stelsel en die daarmee gepaardgaande konstruksie van die saaklike ooreenkoms ontleen word aan Friedrich Carl von Savigny en die Pandektenwissenshaft wat sy konstruksie verder verfyn het. Die vraag wat in hierdie artikel aangespreek sal word is of daar enige aanknopingspunte in die Romeinse reg, in besonder in die tyd van Justinianus, vir 'n abstrakte stelsel aangetref kan word? Is Savigny se teorie betreffende die saaklike ooreenkoms op die Romeinse reg gegrond?

Toe Justinianus in 527 keiser van die Oos-Romeinse ryk geword het, het die Romeinse ryk in 'n staat van verval verkeer. Sy strewe was om die mag, luister en welvaart van die voormalige wêreldryk te herstel, ook wat die regstelsel betref. $^{2}$ Sy grootste nalatenskap op die terrein van die reg, was ongetwyfeld die kodifikasie van die Romeinse reg wat in die jare 528-534 tot stand gekom het en wat gepoog het om, in reaksie op die vulgarisering van die reg, die klassieke reg in ere te herstel. ${ }^{3}$ Wanneer vandag na die Romeinse reg verwys word, word

2 Hy wou 'n terugkeer na die klassieke gedagtes bewerkstellig, vandaar die begrip klassisisme. Feenstra (red) Grondslagen 5; Van Oven Romeinsch Privaatrecht 34; Kop Vulgaire Reg 2-3.

3 Die Justiniaanse kodifikasie, wat sedert die Middeleeue as die Corpus luris Civilis bekend staan, het uit die volgende dele bestaan: (1) Die Digesta (Pandekta) lustinianus wat bestaan het uit uittreksels uit geskrifte van die klassieke Romeinse juriste (ook ius of reg genoem), wat naas keiserlike verordeninge die belangrikste regsbronne was. Dié werk is op 16 Desember 533 gepubliseer en bestaan uit 50 boeke wat onderverdeel is in titels, fragmente en paragrawe. Justinianus het die tekste egter nie in hulle oorspronklike vorm oorgeneem nie, maar veranderinge aangebring. Daar kan dus nie met sekerheid gesê word dat die siening van die betrokke juriste in die Digesta weergegee word nie. Dit is eerder die siening van die kommissie wat die Digesta saamgestel het, of hulle interpretasie van 'n betrokke teks. In elk geval was die tekste waarskynlik reeds gewysig voordat die kommissie dit bewerk het. (2) Die Institutiones lustinianus wat 'n beknopte leerboek was vir gebruik deur studente en wat op die Institutiones van Gaius, aangevul deur uittreksels uit ander ou bronne, gegrond is. Dit bestaan uit vier boeke wat in titels en paragrawe verdeel is en is op 21 November 533 gepubliseer. Dit het dieselfde krag as wetgewing gehad. (3) Die Codex lustinianus wat 'n versameling keiserlike verordeninge (constitutiones of leges) bevat en op 16 November 534 afgekondig is. Dit bestaan uit 12 boeke wat onderverdeel is in titels en konstitusies, wat op hulle beurt weer onderverdeel is in fragmente. Keiserlike verordeninge was in die na-klassieke tydperk die hoofbron van nuwe regsreëls. Nie alleen die verordeninge van Justinianus is in die Codex opgeneem nie, ook die Codex Theodosianus en die Codices Gregorianus en Hermogenianus is as bronne gebruik. (4) Nadat die Codex in 534 verskyn het, het Justinianus nog enkele nuwe verordeninge uitgevaardig wat later as die Novellae aangedui is en wat die vierde 
daarmee hoofsaaklik bedoel die regsreëls wat in die Corpus Iuris Civilis opgeteken is. Die kodifikasie kon egter nie daarin slaag om die klassieke styl en denke weer ten volle te laat herleef nie, omdat die opstellers daarvan gekonfronteer was met 'n weergawe van die klassieke bronne soos wat dit deur die vulgêre reg beïnvloed is enersyds en met praktiese eise andersyds. ${ }^{4}$ Alhoewel die kodifikasie bloot 'n optekening was van bestaande regsreëls afkomstig van vroeëre keisers en juriste uit die klassieke tyd, ${ }^{5}$ het Justinianus sommige verouderde of ingewikkelde reëls en onderskeidings afgeskaf en vereenvoudig. Die onderskeid tussen Quiritiese en praetoriese eiendom en dié tussen res mancipi en res nec mancipi is byvoorbeeld opgehef. ${ }^{6}$ Hierdie hervormings het verreikende tegniese en dogmatiese gevolge gehad, aangesien die ou tekste gewysig en aangepas moes word. Die woorde ex iure Quiritium, res mancipi en res nec mancipi moes byvoorbeeld uit die tekste geskrap word, terwyl mancipatio met traditio vervang is. ${ }^{7}$

Die bespreking in hierdie artikel is daarop gerig om aan te toon in watter opsigte die regsposisie in die tyd van Justinianus van dié in die klassieke en die vulgêre reg verskil het. Aangesien die Corpus Iuris Civilis 'n poging was om die klassieke reg te herstel, kan verwag word dat daar 'n groot mate van ooreenstemming sou wees. Die onderskeid tussen dominium en possessio in die Justiniaanse tydperk is van wesenlike belang vir die verdere bespreking betreffende die wyses van oordrag en die verband wat tussen die verskillende regshandelinge bestaan het. Derhalwe word hierdie begrippe kortliks bespreek.

onderdeel van die kodifikasie uitgemaak het. Raadpleeg Feenstra (red) Grondslagen 1, 6; Lokin Leerstukken 21-22, 25 ev, 32-34; Van Oven Romeinsch Privaatrecht 36-38.

4 Die kodifikasie bevat noodwendig ook vulgêre reg.

5 Anders as wat die geval is met die moderne kodifikasies waar nuwe reëls geformuleer word, is bestaande formulerings oor die algemeen behou.

6 Sien bv Codex 7.25 en 7.31.1.5; Lokin Overdracht 18-19.

7 Die wysigings wat aldus aangebring is, staan bekend as interpolasies. 


\section{Die begrippe dominium en possessio}

In die Justiniaanse reg is possessio as iure possessio opgeneem. ${ }^{8}$ Aangesien die begrip possessio in die eerste plek verwys het na die fisiese beheer van ' $n$ persoon wat besig was om deur verjaring eienaar te word (saaklike funksie), is iure possessio aan civilis possessio gelyk gestel. In aansluiting hierby, en onder invloed van die animus-leer van die Oos-Romeinse ryk, word daar van die standpunt uitgegaan dat 'n possessor die persoon is wat fisiese beheer oor 'n saak uitoefen met die animus domini. ${ }^{9}$ Dit wil sê, in die eerlike geloof dat hy eienaar is; anders gestel, met die bedoeling om fisiese beheer as eienaar uit te oefen (eiebesit). ${ }^{10}$ Possessio animo domino van die Justiniaanse reg verskil dus van die animus possidendi van die klassieke reg, wat bloot verwys het na die bedoeling om fisiese beheer oor ' $n$ saak uit te oefen en wat in die verkryging van daadwerklike beheer tot uiting gekom het. Alle ander vorme van fisiese beheer wat nie as iure possessio in bogenoemde betekenis beskryf kan word nie, is as corpore possessio omskryf, wat met die klassieke naturalis possesio vereenselwig is. ${ }^{11}$

In die klassieke reg is animus en corpus (sover dit die verkryging en verlies van possessio aangaan) nie as twee selfstandige handelinge nie, maar as twee elemente van een en dieselfde handeling gesien. Daar was ' $n$ besondere band tussen hulle wat veral daarin tot uiting gekom het dat die verkryging van fisiese beheer deur die animus gekwalifiseer is. Die feit dat possessio in Justinianus se tyd met die Oos-Romeinse animus-leer gesintetiseer is (wat meer klem op die partye se bedoeling en minder klem op die uiterlike vorm geplaas het), het tot gevolg gehad dat hierdie siening verander het in dié opsig dat die twee elemente al hoe meer van mekaar losgemaak word. ${ }^{12}$ Corpus en animus word

$8 \quad$ Codex 2.14.1.3 en 7.32.10; Digesta 41.2.19.1 en 43.26.15.4.

9 Codex 6.2.21.3; Digesta 41.2.3.22.

10 Kaser Privatrecht II 252-253; Pringsheim 1933 LQR 53 ev. Van der Walt Houerskap 112113 wys daarop dat possessio soms wyd genoeg opgeneem is om ook sekere gevalle van vreemdbesit in te sluit, naamlik ususfructus en ander servitute.

11 Bv fisiese beheer van persone wat nie die animus dominus gehad het nie, soos detentores, en ook interdikbesit en mala fide besit. Kaser Privatrecht II 253; Kaser/Wubbe Romeins Privaatrecht 101; Middelberg Houderschap 22.

12 Hierdie proses het reeds in die na-klassieke wetgewing begin, aangesien die verskaffing 
nou nie meer as twee elemente van een enkele handeling gesien nie, maar as twee selfstandige handelinge, terwyl die animus-vereiste (en nie corpus nie) as die wesenskenmerk van possessio gesien word. ${ }^{13}$ Ook die klassieke beginsel dat possessio met die blote animus alleen behou kan word (animo solo retinere possessionem), is in die Justiniaanse tyd uitgebrei, sodat 'n persoon possessio kon behou selfs al het hy nie op 'n indirekte wyse fisiese beheer oor die saak uitgeoefen nie en selfs al is hy sy beheer op 'n geweldadige wyse ontneem. ${ }^{14}$ Hierdie ontwikkelings, wat aan die vergeesteliking van possessio toegeskryf kan word, het tot gevolg gehad dat possessio al hoe meer van werklike fisiese beheer losgemaak is. ${ }^{15}$ Die begrip iure possessio verwys nou na possessio sonder fisiese beheer. ${ }^{16}$

Die feit dat possessio van fisiese beheer losgemaak is, tesame met die feit dat possessio en dominium in die vulgêre reg vermeng geraak het, het daartoe meegewerk dat possessio in die Justiniaanse reg al hoe meer as 'n eiesoortige reg gesien is wat van eiendomsreg onderskei kon word. ${ }^{17}$ Justinianus se poging om die klassieke eiendomsbegrip te herstel en om dominium weer duidelik van possessio en die beperkte saaklike regte te onderskei, was nie in alle opsigte geslaagd nie, juis omdat die onderskeid tussen dominium en possessio nie duidelik was nie. Aan die een kant word benadruk dat possessio van eiendomsreg onderskei moet word, deurdat die feitlike aard daarvan beklemtoon word, terwyl dominium gesien is as ' $n$ absolute reg op 'n saak. ${ }^{18}$

van fisiese beheer nie meer ' $n$ vereiste in geval van oordrag uit hoofde van ' $n$ koop was nie (wel in geval van skenking). Justinianus het die vereistes wat in die klassieke reg vir die verkryging van possessio gegeld het (corpus et animo) behou, maar dit is van mekaar losgemaak. Kaser Privatrecht II 82-83, 252, 254. Honsell Römisches Recht 140-141.

13 In die Oos-Romeinse ryk was daar 'n neiging om meer klem op die animus-element as op die corpus-element te plaas. Kaser Privatrecht II 251-252, 254.

14 Sien bv Codex 7.32.12 en 8.4.11. In die klassieke tyd het hierdie beginsel 'n beperkte toepassingsgebied gehad. Raadpleeg Kaser Privatrecht II 254-255; Van Oven Romeinsch Privaatrecht 137; Honsell Römisches Recht 141; Pringsheim 1933 LQR 53.

15 Indien die animus die deurslaggewende element is, impliseer dit dat iemand possessio (eiebesit) kon hê, selfs al is hy nie fisies in beheer van die saak nie.

16 Maw, dit het 'n soortgelyke betekenis as wat die begrip possessio solo animo in die klassieke tydperk gehad het. Middelberg Houderschap 22-23.

17 Digesta 4.6.19, 41.2.44 pr en 43.8.2.38. Raadpleeg ook Levy Vulgar Law 72-73; Kaser Privatrecht II 254. In die klassieke tydperk is dit hoofsaaklik as 'n blote feitlike toestand beskou. Dit is interessant om daarop te let dat die verkryging van possessio nie as ' $n$ regshandeling gesien is nie.

18 Levy Vulgar Law 72-73; Van Oven Romeinsch Privaatrecht 137. 
Aan die ander kant word possessio weer losgemaak van fisiese beheer en word dit as 'n reg op fisiese beheer beskou. ${ }^{19}$ Verdere ontwikkelinge in die Justiniaanse reg wat vir die onderhawige ondersoek van belang is, is die volgende:

(a) In die Justiniaanse reg is daar nie met ' $n$ vermoede van eiendomsreg gewerk nie. ${ }^{20}$

(b) Die onderskeid tussen die verskillende soorte eiendomsreg is afgeskaf, naamlik (1) tussen dominium ex iure Quiritium en in bonis esse, (2) tussen res mancipi en res nec mancipi en (3) tussen grond wat in die provinsies geleë is en grond wat in Italië geleë is. Justinianus het ook die dominium duorum in solidum van die vulgêre reg verwerp. ${ }^{21}$ In die Justiniaanse reg bestaan daar dus net een vorm van eiendomsreg, naamlik dominium. Aangesien mancipatio en in iure cessio deur Justinianus afgeskaf is, was traditio die enigste wyse waarop dominium oorgedra kon word.

(c) Justinianus het die actio Publiciana herstel, maar dit het net die persoon wat ' $\mathrm{n}$ verjaringsvatbare saak bona fide en ex iusta causa van die eienaar verkry het, te goede gekom. Die beperkte aanwending van die actio het egter tot gevolg gehad dat dit alle praktiese betekenis verloor het. $^{22}$

(d) 'n lusta causa was nie meer 'n vereiste vir verkryging van eiendomsreg deur verjaring nie. ${ }^{23}$

19 Dit is dus nie meer bloot 'n feitlike toestand nie, dit verkry die kenmerke van 'n reg. Kaser/Wubbe Romeins Privaatrecht 101; Van Oven Romeinsch Privaatrecht 137. Die band tussen possessor en die saak is nou eerder juridies van aard as feitlik. Levy Vulgar Law 72-73.

21 Levy Vulgar Law 81 ev; Feenstra (red) Grondslagen 45-46; Van Oven Romeinsch Privaatrecht 67; Van der Walt Houerskap 111.

22 Van der Walt Houerskap 111.

23 Levy Vulgar Law 192-193; Van der Walt Houerskap 100. 


\section{$3 \quad$ Onderskeid tussen causa en traditio}

Aangesien mancipatio deur Justinianus afgeskaf is, was traditio nou die enigste wyse waarop eiendomsreg ten opsigte van roerende en onroerende goed $^{24}$ oorgedra kon word. Dit wil sê dat eiendomsreg oorgedra is deur die verskaffing van fisiese beheer uit hoofde van 'n causa en nie direk deur die koop of skenking soos in die vulgêre reg nie. ${ }^{25}$ In laasgenoemde regstelsel is daar (soos in die oud-Romeinse reg) geen defnitiewe onderskeid tussen die onderskeie regshandelinge getref nie. ${ }^{26}$ Sluiting van die koopkontrak, betaling van die koopprys en verskaffing van fisiese beheer oor die koopsaak het gelyktydig plaasgevind en dit het terselfdertyd ook oorgang van eiendomsreg bewerkstellig. ${ }^{27}$ In hierdie proses het die wedersydse bedoeling om eiendomsreg oor te dra en te ontvang nie 'n belangrike rol gespeel nie. Aangesien Justinianus wou terugkeer na die grondbeginsels van die klassieke Romeinse reg, het hy weer onderskei tussen die causa (dit wil sê, 'n verbintenis of ander regsfeit wat die vervreemder verplig om die saak te lewer) en die verskaffing van fisiese beheer as oordragshandeling (traditio in die eng sin). ${ }^{28}$ Die algemene reël was dat eiendomsreg oorgaan deur verskaffing van fisiese beheer of deur verjaring en nie deur blote ooreenkoms nie. ${ }^{29}$ Elkeen van hierdie elemente sal vervolgens van naderby beskou word.

\section{$4 \quad$ Fisiese beheer}

Soos wat reeds aangetoon is, onderskei die konstruksie van die saaklike ooreenkoms tussen die causa en verskaffing van fisiese beheer as twee afsonderlike regshandelinge. In die Suid-Afrikaanse reg speel die verskaffing

24 Daar was geen verskil tussen oordrag van roerende en onroerende goed nie.

25 Institutiones 2.1.40-48; Levy Vulgar Law 148; Kaser Privatrecht II 282; Lokin Overdracht 19.

26 Sien Schutte 2000 PER 4-6 http://www.puk.ac.za/ 30 Mei.

27 Totstandkoming van die koopkontrak was tegelykertyd ook saaklike oordragshandeling.

28 Die skeiding tussen persoonlike reg en saaklike reg word egter verklein deurdat ' $n$ actio in rem in sommige gevalle verleen word indien die causa wegval. Kaser Privatrecht II 282; Levy Vulgar Law 156.

29 Codex 2.3.20; Feenstra (red) Grondslagen 61; Dondorp en Schrage Levering 26. 
van fisiese beheer 'n belangrike rol by die oordrag van eiendomsreg. Behoudens enkele uitsonderingsgevalle kan eiendomsreg nie oorgaan nie, tensy die verkryger fisies in beheer van die saak gestel word. ${ }^{30}$ Die verskaffing van fisiese beheer alleen is egter nie voldoende nie, aangesien dit gepaard moet gaan met die bedoeling om eiendomsreg oor te dra en te ontvang (die saaklike ooreenkoms).

In die tyd van Justinianus was die algemene reël steeds, soos in die klassieke reg, dat possessio corpore et animo aan die verkryger verskaf moes word. ${ }^{31}$ Dit wil sê dat die verkryger fisiese beheer oor die saak moes vestig met die bedoeling om eienaar te word. ${ }^{32}$ Hierbo is opgemerk dat die verskaffing van fisiese beheer in die tyd van Justinianus nietemin op die agtergrond geraak het (die corpus-element is verslap) en dat die animus-vereiste al hoe meer beklemtoon is. Dit blyk onder andere daaruit dat dit moontlik was om possessio te verkry, selfs al het die verkryger die saak nie werklik fisies hanteer nie. Lewering was byvoorbeeld moontlik bloot deur fisiese aanraking of sintuiglike waarneming van die saak ${ }^{33}$ en selfs deurdat die verkryger beheer oor die saak gevestig het, sonder dat die saak werklik aangeraak of waargeneem is. ${ }^{34}$ Wat die oordrag van grond betref, kan daarop gewys word dat dit in die tyd van Justinianus moontlik was dat die oordraggewer die verkryger kon magtig om fisiese beheer oor die grond eensydig in sy afwesigheid te vestig - traditio inter absentes. ${ }^{35}$ Oorhandiging deur die oordraggewer en die verkryging van fisiese beheer deur die verkryger is in hierdie geval in tyd en ruimte van mekaar

30 Dit gee uiting aan die publisiteitsbeginsel.

31 Codex 2.3.20; Digesta 41.1.55; Levy Vulgar Law 148, 150 ev; Kaser Privatrecht II 283; Lokin Overdracht 20; Dondorp en Schrage Levering 26.

32 In die klassieke reg het die begrip animus nie na die bedoeling om eienaar te wees verwys nie (animus domino), maar na die bedoeling om fisiese beheer uit te oefen (animus possidendi).

33 Soos bv waar die grense van die grond vanuit 'n nabygeleë toring aangewys is, of waar die sleutels van ' $n$ wynkelder oorhandig is. In die klassieke tyd moes die sleutels in nabyheid van die kelder oorhandig word sodat dit sintuiglik waargeneem kon word. In die tyd van Justinianus was nabyheid of teenwoordigheid van die gebou nie meer 'n vereiste nie. Kaser Privatrecht II 283.

34 Bv die aanstel van 'n wag by 'n klomp hout. Lokin Overdracht 19-20; Kaser Privatrecht II 283.

35 Dit is die missio in vacuam possessionem waarvan in Digesta 41.2.18.2 melding gemaak word. 
geskei. $^{36}$ Ook traditio brevi manu en constitutum possessorum (waarna gewoonlik verwys word as traditio solo animo) is erken as wyses waarop eiendomsreg oorgedra is, ${ }^{37}$ terwyl retentio ususfructus daagliks gebruik was, alhoewel dit nie deur die reg gesanksioneer is nie. ${ }^{38}$ Soos wat hierbo aangetoon is, is die beginsel van animo retinere possessionem ook uitgebrei. Die verskaffing van werklike fisiese beheer is egter nog nie deur 'n blote simboliese handeling, soos byvoorbeeld oorhandiging van ' $\mathrm{n}$ akte, vervang nie. ${ }^{39}$ Traditio per cartam was dus nie 'n erkende wyse van oordrag nie. ${ }^{40}$

In die lig van hierdie besondere vorme van traditio is dit duidelik dat die woord tradere nie meer so 'n skerp omlynde betekenis soos in die klassieke tyd gehad het nie, maar dat 'n ruim betekenis aan die algemene reël soos byvoorbeeld in Codex 2.3.20 vervat, geheg moet word. ${ }^{41}$ Daar word selfs beweer dat die vorme van traditio waarna hierbo verwys is en waar bykans geen fisiese kontak was nie, voorbeelde is van gevalle waar eiendomsreg deur blote wilsooreenstemming oorgegaan het en dat die begrip traditio in die Corpus luris Civilis in twee betekenisse gebruik is, naamlik (1) oordrag van eiendomsreg deur die verskaffing van fisiese beheer ${ }^{42}$ en (2) oordrag van eiendomsreg op grond van 'n ooreenkoms. ${ }^{43}$

Enkele tekste skep die indruk dat die verkryging van eiendomsreg moontlik was, selfs al is die verkryger nie werklik fisies in beheer van die saak gestel nie. In Digesta 23.5.16, byvoorbeeld, word die geval aangetref waar 'n vrou 'n stuk grond aan haar man as bruidskat gegee het, terwyl nog sy, nog haar man

36 Gordon Traditio 51; Delport Lewering en Registrasie 119-120.

37 Mits daar voldoen is aan die ander vereistes vir die oordrag van eiendomsreg. Terwyl daar twyfel bestaan oor die vraag of constitutum possessorum in die klassieke reg erken is, is dit seker dat dit wel in die Justiniaanse reg as wyse van traditio erken is. Institutiones 2.1.44; Delport Lewering en Registrasie 110.

38 Levy Vulgar Law 151-152.

39 Feenstra (red) Grondslagen 61; Kaser Privatrecht II 283.

40 Van Oven Romeinsch Privaatrecht 73-74 is egter van oordeel dat eiendomsreg in die praktyk dikwels slegs deur 'n akte oorgedra is, sonder dat daadwerklike fisiese beheer verskaf is.

41 Feenstra (red) Grondslagen 61.

42 Hoofsaaklik vir die oordrag van maklik hanteerbare sake soos juwele, geldstukke, wyn, skilderye, ens.

43 Van Oven Romeinsch Privaatrecht 73. 
persoonlik op die grond teenwoordig was. Iemand anders, naamlik Titius, was fisies in beheer van die grond. Ingevolge die teks het die eggenoot wel eienaar geword. Dit wil dus voorkom of dominium deur traditio verkry is sonder dat die man fisies in beheer gestel is. ${ }^{44}$ Daar moet egter daarop gewys word dat die vrou die grond in die oorspronklike teks by wyse van mancipatio aan haar man oorgedra het, in welke geval die grond in absentia oorgedra kon word. Aangesien die begrip mancipatio deur Justinianus in die tekste met traditio vervang is, is dit twyfelagtig of hierdie teks werklik gesag is daarvoor dat eiendomsreg as ' $n$ reël deur traditio oorgedra kon word indien die verkryger nie werklik fisies in beheer van die saak gestel nie.

Die gevolgtrekking is dat alhoewel possessio al hoe meer losgemaak is van fisiese beheer en dit die kenmerke van 'n reg vertoon het, een of ander vorm van fisiese kontak, hoe gering ook al, steeds in beginsel ' $n$ vereiste vir die oordrag van eiendomsreg was. Ook die feit dat meer klem op die animuselement geplaas is, het nie hieraan afbreuk gedoen nie. Daar is slegs in uitsonderlike gevalle van hierdie vereiste afgesien. ${ }^{45}$ Hierdie standpunt word bevestig deur die praktyk waardeur die feit van fisiese oorhandiging in geval van koop en skenking in munisipale registers aangeteken is.

\section{$5 \quad$ Uitwendige abstraksie - die iusta causa}

Soos wat reeds opgemerk is, is daar in die Justiniaanse tyd, anders as in die vulgêre reg, wel tussen causa en die verskaffing van fisiese beheer (traditio in die eng sin) onderskei. Fisiese beheer opsigself het egter nog nie oorgang van eiendomsreg bewerkstellig nie. Eiendomsreg sou in die reël slegs oorgaan indien fisiese beheer uit hoofde van 'n iusta causa oorgedra is. Die causa was gewoonlik een of ander verbintenis wat die oordraggewer verplig het om die saak oor te dra, soos byvoorbeeld 'n koopkontrak. Anders as in die vulgêre reg, het die koopkontrak nie deur betaling van die koopprys of oorhandiging van

44 Dondorp en Schrage Levering 29.

45 Soos bv in geval van constitutum possessorium en waar oordrag aan 'n kerk of munisipaliteit plaasgevind het. Levy Vulgar Law 149, 151, 155. 
arrha tot stand gekom nie, maar deur wilsooreenstemming (konsensus). ${ }^{46}$ In die tyd van Justinianus het eiendomsreg ook nie deur sluiting van die verbintenisskeppende ooreenkoms oorgegaan nie; fisiese beheer moes verskaf word.

Kenmerkend van 'n abstrakte stelsel is dat die nietigheid van die verbintenisskeppende ooreenkoms nie noodwendig verhinder dat eiendomsreg deur lewering oorgaan nie. Die vraag ontstaan dus of die causa in geval van koop en skenking in die tyd van Justinianus geldig moes wees ten einde oordrag van eiendomsreg tot gevolg te hê (was 'n iusta causa 'n vereiste)? In die klassieke tydperk het daar oor hierdie vraag geen duidelikheid bestaan nie. Ook in die tyd van Justinianus was daar geen sekerheid in hierdie verband nie. ${ }^{47}$ Aan die een kant word tekste in die Corpus Iuris Civilis aangetref wat steun bied vir die standpunt dat oordrag van eiendomsreg kousaal was: ${ }^{48}$

Die blote verskaffing van fisiese beheer is nie voldoende om eiendomsreg oor te dra nie. Eiendomsreg gaan slegs oor indien fisiese beheer verskaf word uit hoofde van 'n koop of ander iusta causa wat traditio voorafgaan. ${ }^{49}$

Daar word aanvaar dat die begrip iusta causa in hierdie teks na 'n objektief geldige causa verwys, wat impliseer dat eiendomsreg nie sal oorgaan nie indien die causa nietig was, of indien die voorganger nie eienaar was nie. ${ }^{50} \mathrm{n}$ Kousale stelsel word verder ondersteun deur (1) Digesta 12.1.18 pr waar Ulpianus oënskynlik die standpunt ingeneem het dat eiendomsreg nie oorgaan

46 Institutiones 3.23 pr. Levy Vulgar Law 149-152, 155-156. Skrif was ook nie 'n geldigheidsvereiste nie.

47 Kaser Privatrecht II 282; Ehrhardt lusta causa 187 ev; Pringsheim 1933 LQR 56. Aangesien ons rekonstruksie van die regsposisie in die klassieke tyd hoofsaaklik op die Digesta van Justinianus berus waarin tekste van die klassieke juriste opgeneem is, spreek dit vanself dat daar 'n groot mate van ooreenstemming sal wees tussen die bespreking van die klassieke tydperk hierbo en die Justiniaanse reg.

48 Ook die volgende skrywers is van oordeel dat ' $n$ kousale stelsel van toepassing was: Feenstra (red) Grondslagen 62, 64; Lokin Overdracht 19-20; Lokin Leerstukken 166-167; Dondorp en Schrage Levering 27, 29; Kaser Privatrecht I 416-417; Zimmermann Obligations 271.

49 Digesta 41.1 .31 pr: "Numquam nuda traditio transfert dominium, sed ita, si venditio aut aliqua iusta causa praecesserit, propter quam traditio sequeretur (eie vertaling)". Sien ook Digesta 12.1.18 pr.

50 Maar sien Van Oven Romeinsch Privaatrecht 77 wat meen dat hierdie teks nie gesag is vir die stelling dat die begrip iusta causa na 'n objektief geldige causa verwys nie. 
nie indien daar vanweë dwaling nie 'n geldige voorafgaande verbintenis (causa) was nie; ${ }^{51}$ (2) die reël dat eiendomsreg nie oorgegaan het nie indien 'n saak uit hoofde van 'n nietige koopkontrak (vanweë strydigheid met wetgewing) gelewer is; $^{52}$ (3) die reël wat skenkings tussen eggenote verbied het; ${ }^{53}$ (4) die prysbetalingsreël. Ingevolge hierdie reël het eiendomsreg nie deur die verskaffing van fisiese beheer oorgegaan nie, maar slegs indien die koopprys betaal is, of indien sekuriteit vir betaling van die koopprys verskaf is, of indien die koper ' $n$ formele betalingsbelofte deur middel van stipulatio gedoen het. ${ }^{54}$ Alhoewel hierdie reël ook deur Justinianus gehandhaaf is, ${ }^{55}$ het hy soos in die klassieke tyd, 'n uitsondering toegelaat indien krediet verleen is. Hierdeur is die praktiese effek van die reël geneutraliseer, want indien die verkoper fisiese beheer verskaf het en die koper nog nie betaal het nie, is daaruit afgelei dat die verkoper stilswyend krediet verleen het en dat hy genoeë geneem het met uitstel van betaling. Eiendomsreg het dus oorgegaan sodra die verkoper fisiese beheer oordra, selfs al het hy nog nie betaling ontvang nie. ${ }^{56}$

Aan die ander kant word weer tekste aangetref wat steun bied vir die standpunt dat ' $n$ abstrakte stelsel in die Justiniaanse reg toegepas is. ${ }^{57}$ Een so 'n teks is Institutiones 2.1.40:

Ook deur verskaffing van fisiese beheer (traditio) verkry ons sake ooreenkomstig die natuurlike reg (ius naturale). Want niks is meer in

51 Codex 2.3.6. Daar bestaan egter twyfel oor die korrekte interpretasie van hierdie teks; in elk geval het dit nie 'n algemene reël neergelê nie.

52 Die verkryger sou slegs die beskerming wat possessio verleen het geniet, soos bv om eienaar te word deur verjaring, of om in 'n regsgeding van die bewyslas onthef te word. Lokin Overdracht 20.

53 Anders as in die klassieke reg was skenkings in die tyd van Justinianus wel verbintenisskeppende ooreenkomste. As die ooreenkoms nietig was, bv omdat dit regtens verbode was (soos skenkings tussen eggenote), sou eiendomsreg ook nie deur lewering oorgaan nie.

54 Die argument is dat die koopkontrak eers bindend geword het indien die koopprys betaal is (betaling was ' $n$ element van kontraksluiting). Sodra die koopprys betaal is, het die verkryger eienaar geword en het hy die reg verkry om lewering van die koopsaak te eis. Zimmermann Obligations 275-276; Molkenteller Dinglichen Vertrag 64; Lokin Leerstukken 173-174.

55 Sien bv Institutiones 2.1.41; Digesta 18.1.19 en 18.1.53.

56 Kaser Privatrecht II 284; Feenstra (red) Grondslagen 64-65; Van Oven Romeinsch Privaatrecht 81; Honsell Römisches Recht 161; Lokin Leerstukken 173; Zimmermann Obligations 275-276.

57 Raadpleeg Kaser Privatrecht II 282; Ehrhardt Iusta Causa 175; Pringsheim 1933 LQR 53 ev; Levy Vulgar Law 149. 
ooreenstemming met natuurlike billikheid nie, as dat mens gevolg gee aan die bedoeling van die eienaar wat sy saak aan 'n ander oordra. $^{58}$

Alhoewel hier nie uitdruklik gesê word dat 'n iusta causa geen vereiste vir die oordrag van eiendomsreg is nie, wil dit tog voorkom of die bedoeling van die partye (die voluntas domini volentis rem suam in alium transferre) deurslaggewend was vir die oordrag van eiendomsreg deur traditio eiendomsreg gaan oor, selfs al is daar geen geldige causa nie, mits dit die bedoeling van die partye is om eiendomsreg oor te dra. ${ }^{59}$ Institutiones 2.1 .40 vind aansluiting by Digesta 41.1.36 waar Julianus ook die bedoeling om eiendomsreg oor te dra en te ontvang beklemtoon, wat hy belangriker ag as die vraag of daar 'n geldige voorafgaande verbintenis is. ${ }^{60}$

Verdere steun vir 'n abstrakte stelsel kan gevind word in daardie gevalle waar eiendomsreg oorgegaan het, nieteenstaande die feit dat daar geen verbintenisskeppende ooreenkoms was nie, of selfs al was die causa nietig, soos wat die geval met die bruidskat, ${ }^{61}$ solutio, donatio en mutuum was. Daar moet egter daarop gewys word dat donatio in die tyd van Justinianus verskil het van donatio in die klassieke reg. In die klassieke reg was die skenking nie 'n erkende en selfstandige verbintenisskeppende ooreenkoms nie. Die skenking het eers deur lewering van die saak tot stand gekom en was dus niks anders nie as 'n wyse waarop eiendomsreg oorgedra is. Die oorsaak of causa vir die oordrag van eiendomsreg was in die bedoeling om te skenk geleë. ${ }^{62}$ In die tyd van Justinianus is die skenking ${ }^{63}$ wel as 'n selfstandige verbintenisskeppende

58 Institutiones 2.1.40: "Per traditionem quoque iure naturali re nobis adquiruntur: nihil enim tam conveniens est naturali equitati, quam voluntatem domini, volentis rem suam in alium transferre, ratam haberi (eie vertaling)".

59 Die feit dat die causa nietig is, verander niks aan die bedoeling van die partye nie en dit is wat deurslaggewend is. Maar sien Feenstra (red) Grondslagen 64 wat meen dat Institutiones 2.1.40 niks te make het met die vraag of ' $n$ objektief geldige causa ' $n$ vereiste vir die oordag van eiendomsreg was nie.

60 Ander tekste wat die bedoeling beklemtoon is oa Digesta 39.5.10, 47.2.14.17, 41.1.36 en 41.1.9.3.

61 'n Stuk grond wat as bruidskat oorgedra is kon bv met die condictio (en nie die rei vindicatio nie) teruggeëis word indien geen huwelik later voltrek word nie. Digesta 12.4.7.1. Sien ook Levy Vulgar Law 171; Dondorp en Schrage Levering 27.

62 Zimmermann Obligations 480-481.

63 En waarskynlik mutuum ook alhoewel daar nie sekerheid hieroor is nie. 
ooreenkoms erken wat deur konsensus tot stand gekom het en wat die causa vir oordrag van eiendomsreg was. Die mondelinge skenkingsbelofte was dus afdwingbaar en dit was nie meer nodig om van 'n stipulatio gebruik te maak nie. ${ }^{64}$ Die skenking in die vorm waarin dit in die klassieke reg bestaan het, naamlik die oordrag van 'n saak met die bedoeling om dit te skenk sonder dat daar ' $n$ voorafgaande verbintenis bestaan het, is nogtans erken. ${ }^{65}$

'n Ander aspek wat die indruk mag skep dat 'n abstrakte stelsel in die Justiniaanse tyd gegeld het, was die feit dat Justinianus mancipatio in 'n aantal tekste met traditio vervang het. Aangesien 'n causa nie by mancipatio vereis is nie (mancipatio was abstrak), kon hierdie tekste in hulle veranderde vorm die indruk skep dat 'n iusta causa nie meer by traditio 'n vereiste was nie. Die sterkste argument ten gunste van die standpunt dat ' $n$ abstrakte stelsel van oordrag in die Justiniaanse reg van toepassing was, is egter die bestaan van die condictiones (actiones in personam). Die condictiones sine causa kan slegs verklaar word op die aanname dat 'n geldige voorafgaande ooreenkoms nie ' $n$ vereiste vir die oordrag van eiendomsreg was nie. Die Justiniaanse reg kan daarom moeilik as 'n kousale stelsel beskryf word. ${ }^{66}$

Die gevolgtrekking uit die bespreking hierbo is dat daar, soos in die klassieke tydperk, nie duidelikheid bestaan oor die vraag of die stelsel in die tyd van Justinianus kousaal dan wel abstrak was nie. Daar kan steun vir beide stelsels in die tekste aangetref word. In gevalle waar oordrag uit hoofde van koop of skenking plaasgevind het, het nietigheid van die voorafgaande causa ook verhinder dat eiendomsreg oorgaan. In hierdie opsig is daar dus geen sprake van die uitwendige abstraksie nie. In gevalle waar oordrag plaasgevind het op grond van 'n bruidskat, mutuum of in geval van solutio uit hoofde van 'n

64 Kenmerkend van die ooreenkoms was die bedoeling om te skenk (animus donandi) wat slegs in sekere omstandighede herroep kon word.

65 Institutiones 2.7.2, Codex 8.53.35.5b, Novellae 162.1, Codex 4.21.17 pr. Raadpleeg ook Levy Vulgar Law 152 ev; Kaser Privatrecht II 396 ev; Van Zyl Romeinse Privaatreg 324325; Zimmermann Obligations 494-495.

66 Dondorp en Schrage Levering 27; Van Oven Romeinsch Privaatrecht 79; Carey Miller Acquisition 126. 
stipulatio was oordrag egter nie van 'n geldige causa afhanklik nie. In hierdie opsig kan daar dus wel kenmerke van 'n uitwendige abstraksie bespeur word.

\section{Inhoudelike abstraksie - die rol en funksie van die bedoeling om eiendomsreg oor te dra}

Soos wat hierbo aangetoon is, is eiendomsreg in die tyd van Justinianus deur traditio oorgedra, wat uit die volgende elemente bestaan het: ${ }^{67}$ (1) 'n iusta causa in die betekenis van 'n voorafgaande regsfeit wat die vervreemder verplig om die saak te lewer en wat geskik was om eiendomsoordrag te bewerkstellig (byvoorbeeld 'n verbintenisskeppende ooreenkoms soos 'n koopkontrak) en (2) lewering wat uit twee elemente bestaan het, naamlik die verkryging van fisiese beheer (corpus) met die bedoeling om fisiese beheer as eienaar uit te oefen (animus dominus). Vir die onderhawige ondersoek is dit van belang om te weet of enige kenmerke van die inhoudelike abstraksie in die tyd van Justinianus aangetref is. Het die bedoeling om eiendomsreg oor te dra en te ontvang 'n selfstandige bestaan onafhanklik van die verbintenisskeppende ooreenkoms gevoer? Daar is aanduidings daarvan dat dit wel die geval kon wees. Hierdie tekens sal vervolgens van naderby beskou word alvorens ' $n$ finale standpunt ingeneem kan word.

(a) Institutiones 2.1.40 verwys slegs na die bedoeling van die vervreemder om eiendomsreg oor te dra, maar daar is ander tekste wat vereis dat ook die verkryger die bedoeling moes hê om eiendomsreg te ontvang. ${ }^{68}$ Daar kan dus 'n sterk argument uitgemaak word daarvoor dat traditio 'n tweesydige handeling was wat op die bewustelike medewerking van die partye berus het. Dit impliseer dat daar wilsooreenstemming moes wees daaroor dat eiendomsreg deur lewering oorgedra word en dat traditio op

67 Lokin Overdracht 19; Dondorp en Schrage Levering 26. Die reël was dieselfde as in die klassieke tyd. Anders as in die vulgêre reg, was ' $n$ afsonderlike leweringshandeling nodig; eiendomsreg het nie oorgegaan deur sluiting van die koopkontrak (causa) nie.

68 Sien bv Digesta 44.7.55 en Codex 4.50.9. Ook die animus-element wat deel was van die leweringsvereiste, verwys na die bedoeling van die verkryger. 
'n (saaklike) ooreenkoms tussen die partye berus het. ${ }^{69}$ Dit was egter nie die geval nie. Daar is geen teks in die Corpus Iuris Civilis wat twee ooreenstemmende wilsverklarings wat op die oordrag van eiendomsreg gerig is, vereis het nie. Die rede hiervoor kan gevind word in die feit dat daar slegs twee vereistes vir die oordrag van eiendomsreg was, naamlik 'n iusta causa (byvoorbeeld koopkontrak) en lewering (traditio in die eng sin). Die koopkontrak het 'n dubbele rol vervul: (1) dit het 'n verbintenis tot stand gebring wat die vervreemder verplig het om die koopsaak te lewer en (2) dit het gedien as iusta causa traditionis - dit was die rede of oorsaak vir lewering en het implisiet ook die partye se bedoeling omvat. Een van die kenmerke van 'n geskikte causa was immers dat die partye bedoel het om eiendomsreg oor te dra. ${ }^{70}$ Die wedersydse bedoeling om eiendomsreg oor te dra en te ontvang was dus nie 'n afsonderlike vereiste nie, dit was in die verbintenisskeppende ooreenkoms vervat. ${ }^{71}$ Soos in die klassieke reg was die oordrag van eiendomsreg in die tyd van Justinianus dus nog geen konsensuele ooreenkoms nie. Die wedersydse bedoeling om eiendomsreg oor te dra en te ontvang is nie as 'n selfstandige (saaklike) ooreenkoms wat bloot deur wilsooreenstemming tot stand kom, gekonstrueer nie. 'n Belangrike kenmerk van die inhoudelike abstraksie het dus ontbreek.

(b) Daardie gevalle waar fisiese beheer verkry is sonder dat die verkryger die saak werklik fisies hanteer het, ${ }^{72}$ skep die indruk dat eiendomsreg deur blote ooreenkoms (wilsooreenstemming) oorgedra is (mits natuurlik

69 Kaser Privatrecht II 282. Tekste soos hierdie is juis deur Savigny gebruik as gesag daarvoor om die bedoeling van die partye van die grondliggende causa los te maak en daarvan 'n selfstandige ooreenkoms te maak.

70 Raadpleeg Zimmermann Obligations 239-240, 278-279. Hy wys daarop dat die koopkontrak al die elemente bevat het wat nodig was om eiendomsreg oor te dra, behalwe lewering. Dit het beteken dat eiendomsreg oorgegaan het sodra lewering plaasgevind het.

71 Maar sien Dondorp en Schrage Levering 29 wat van oordeel is dat die bedoeling sakeregtelik van aard is, en nie aan kontraktuele wilsooreenstemming gelykgestel kan word nie.

72 Soos bv waar 'n stuk grond vanuit 'n hoë gebou aangewys is; waar 'n saak binne die magsbereik (kontrole) van die verkryger gebring is; waar 'n akte oorhandig is sonder dat daadwerklike fisiese beheer oorgedra is; ook oordrag by wyse van constitutum possessorium en traditio brevi manu. 
ook aan die ander vereistes voldoen is). ${ }^{73}$ Hierdie indruk word ondersteun deur die feit dat die corpus en animus-elemente van lewering al hoe meer van mekaar losgemaak is en dat die animus in die na-klassieke tydperk in belangrikheid toegeneem het. Dit moet egter nie uit die oog verloor word nie dat daar ook in hierdie gevalle minstens een of ander fisiese kontak, hoe gering ookal, moes gewees het, byvoorbeeld aanraking met die oë of blote fisiese teenwoordigheid. In teorie is dus steeds vasgehou aan die corpus-vereiste. ${ }^{74}$ Die gevalle waar geen fisiese element hoegenaamd was nie (traditio solo animo), was werklik uitsonderlike gevalle. Dit is egter te betwyfel of die juriste in die tyd van Justinianus hierdie gevalle teoreties sou verklaar as eiendomsoordrag deur blote ooreenkoms. ${ }^{75}$ Die bedoeling om eiendomsreg oor te dra en te ontvang (animus) het byvoorbeeld nie 'n selfstandige bestaan, onafhanklik van die causa (verbintenisskeppende ooreenkoms) gevoer nie; dit was juis daarin opgesluit. Ook in hierdie gevalle was daar dus geen sprake van 'n inhoudelike abstraksie nie (selfs al is daar in die na-klassieke tydperk al hoe meer klem op die animus geplaas).

(c) Hierbo is opgemerk dat Institutiones 2.1.40 steun bied vir 'n abstrakte stelsel, omdat die bedoeling om eiendomsreg oor te dra deurslaggewend is vir die oordrag van eiendomsreg en die causa traditionis onderbeklemtoon word. Die teks is daarom vatbaar vir die interpretasie dat eiendomsreg kan oorgaan selfs al is die causa nietig, mits dit die partye se bedoeling is. Nietigheid van die causa verander immers niks aan die bedoeling van die partye nie. Dit is egter twyfelagtig of hierdie teks gesag is daarvoor dat die wedersydse bedoeling om eiendomsreg oor te dra van die grondliggende causa losgemaak is en onafhanklik daarvan gefunksioneer het. Die teks is in 'n heel ander verband gemaak

73 Codex 4.21.12 en Codex 4.38.12; Kaser Privatrecht I 391-392; Dondorp en Schrage Levering 29; Lokin Overdracht 19-20; Van Oven Romeinsch Privaatrecht 73-74; Van Oven Besitsbescherming 105; Honsell Römisches Recht 138-139 vn 16-18; Gordon Traditio 62 ev; Delport Lewering en Registrasie 139, 188; Weiss Institutionen 180.

74 Honsell Römisches Recht 138-139; Dondorp en Schrage Levering 18-19.

75 Kaser Privatrecht II 283; Delport Lewering en Registrasie 195, 204-205; Dondorp en Schrage Levering 26. 
en het niks te make met die vereistes vir die oordrag van eiendomsreg nie. ${ }^{76}$ Al wat die samestellers van die Institutiones met hierdie teks in gedagte gehad het, was om aan te toon dat eiendomsreg in geval van traditio oorgaan indien die causa van so ' $n$ aard is dat dit oordrag van eiendomsreg regverdig. ${ }^{77} \mathrm{Nou}$ is dit so dat die onderskeid tussen verbintenisse (causae) wat geskik is om oordrag van eiendomsreg te bewerkstellig en daardie wat nie oordrag van eiendomsreg tot gevolg kan hê nie, juis geleë is in die feit dat die partye op die stadium waarop eersgenoemde ooreenkomste gesluit word, die bedoeling het om eiendomsreg oor te dra. ${ }^{78}$ Die bedoeling is dus nog nie van die causa losgemaak nie, dit is juis daarin opgesluit.

Alhoewel Institutiones 2.1.40 nie gesag is daarvoor dat kenmerke van die inhoudelike abstraksie in die tyd van Justinianus aangetref is nie, bewys dit nietemin dat die bedoeling om eiendomsreg oor te dra in hierdie tyd op die voorgrond gestel is en dat al hoe minder klem op die causa traditionis geplaas is. ${ }^{79}$ Dit blyk uit die feit dat hierdie teks op Digesta 41.1.9.3 gegrond is, wat waarskynlik afkomstig is uit die res cottidianae wat 'n na-klassieke verwerking van Gaius se Institutiones was. Terwyl Gaius in Institutiones 2.20 nog die gedagte dat traditio op 'n causa gegrond moet wees beklemtoon, word die bedoeling om eiendomsreg oor te dra in Institutiones 2.1 .40 op die voorgrond gestel. ${ }^{80}$ Hierdie feit dien as bevestiging daarvan dat daar in die Justiniaanse reg 'n klemverskuiwing plaasgevind het.

(d) Digesta 41.1.36 kan geïnterpreteer word as sou dit kenmerke van die inhoudelike abstraksie vertoon, aangesien Julianus oënskynlik die causa

76 Feenstra (red) Grondslagen 64; Lange Kausale Element 10-16; Molkenteller Dinglichen Vertrag 70-71.

77 Die gedagte was voorts om die verskil tussen traditio en mancipatio, wat nou afgeskaf is, duidelik te maak en om die grondslag vir oorgang van eiendomsreg in geval van traditio aan te toon.

78 Dit is hoekom hulle bv 'n koopkontrak sluit en nie 'n huurkontrak nie.

79 Honsell Römisches Recht 159-160; Molkenteller Dinglichen Vertrag 70; Voß Recht und Rhetorik 178.

80 Kaser Privatrecht II 282-283; Honsell Römisches Recht 159-160; Molkenteller Dinglichen Vertrag 70. 
en die bedoeling van mekaar losgemaak het. Die teks skep die indruk dat nietigheid van die causa nie verhinder dat eiendomsreg oorgaan nie en dat die vraag of die partye die bedoeling het om eiendomsreg oor te dra, deurslaggewend is. Dit moet egter in gedagte gehou word dat hierdie teks nie 'n algemene reël neergelê het nie, dat dit vir meer as een interpretasie vatbaar is ${ }^{81}$ en dat dit waarskynlik geïnterpoleer was (daar bestaan dus twyfel oor die egtheid daarvan). Dit is dus nie baie sterk gesag vir die stelling dat die stelsel in die tyd van Justinianus abstrak van aard was en dat eiendomsreg oorgegaan het bloot ten gevolge van die bedoeling van die partye, wat van die causa losgemaak is nie. ${ }^{82}$ Die feit dat die teks verwerk is toe die Digesta saamgestel is, is nietemin ' $n$ aanduiding daarvan dat daar in die tyd van Justinianus meer klem geplaas is op die bedoeling van die partye as wat in die klassieke reg die geval was. ${ }^{83}$

(e) Die beklemtoning van die partye se bedoeling in die Justiniaanse reg kom ook duidelik na vore in die Paraphrasis Institutionum, die Griekse vertaling van die Institutiones Justinianus deur Theophilus. ${ }^{84}$ Hy het homself nie net beperk tot die woordelikse vertaling van die teks nie, maar ook kommentaar gelewer waarin sy eie standpunt weergegee is. In sy kommentaar op Institutiones 2.1.40 het Theophilus geskryf dat die bedoeling van die oordraggewer op die oordrag van eiendomsreg gerig moet wees, in plaas daarvan om te sê dat dit op die oordrag van die saak gerig moet wees. ${ }^{85}$ Hy het verder besondere klem gelê op die feit dat lewering met die bedoeling om eiendomsreg oor te dra moet

81 Hierdie teks was waarskynlik nie van toepassing op die geval waar die causa nietig was nie.

82 Volgens Hazewinkel-Zuringa Mancipatio 139 was Julianus van oordeel dat eiendomsreg oorgaan omdat hy die standpunt ingeneem het dat 'n persoon wat sy saak aan iemand anders skenk, nie toegelaat moet word om dit met die rei vindicatio terug te vorder nie, selfs al is die causa gebrekkig. Sy standpunt het dus niks met ' $n$ abstrakte stelsel te make nie.

83 Sien ook Molkenteller Dinglichen Vertrag 70.

84 Theophilus was professor aan Konstantinopel se regskool en lid van die kommissies wat die Digesta en Institutiones opgestel het. Die grootste gedeelte van die inwoners van die Oos-Romeinse ryk was Griekssprekend, terwyl die wetgewing in Latyn verskyn het omdat dit die amptelike taal was.

85 Dit is hoe hy die situasie verstaan het. 
geskeid. Die bedoeling om eiendomsreg oor te dra, was egter nog nie van die causa losgemaak nie, dit het steeds verwys na die bedoeling op die tydstip waarop die verbintenisskeppende ooreenkoms (causa) gesluit word. ${ }^{86}$ Die teks het in elk geval nie te make met die vereistes vir die oordrag van eiendomsreg nie.

(f) 'n Verdere aanduiding daarvan dat die band tussen traditio en die causa begin verbrokkel het, word gevind in aantekeninge wat Kyrillos op die Basilica geskryf het. ${ }^{87}$ Met verwysing na Digesta 12.1 .18 pr. en Basilicum 23.1.18 ${ }^{88}$ het Kyrillos die mening uitgespreek dat eiendomsreg nie oorgaan nie indien die ontvanger van 'n skenking dit as ' $n$ lening aanvaar. Ten einde die vraag te beantwoord of eiendomsreg oorgaan al dan nie, het hy die geldigheid van die causa heeltemal buite rekening gelaat en slegs klem gelê op die feit dat die partye nie die wedersydse bedoeling het om eiendomsreg oor te dra nie. Die feit dat nie die causa nie, maar slegs die bedoeling van die partye in aanmerking geneem word by beantwoording van die vraag of eiendomsreg oorgaan, is 'n aanduiding van die verandering in denkwyse wat ingetree het. Dit wil voorkom of 'n abstrakte stelsel voorgestaan is. Die negering van die causa dien hier egter slegs die doel om die bespreking te vereenvoudig, dit regverdig nog nie die standpunt dat daar in die Justiniaanse reg sprake daarvan was dat traditio en die gepaardgaande bedoeling om eiendomsreg oor te dra selfstandig, dit wil sê los van die causa, gefigureer het nie. ${ }^{89}$

(g) Die sterkste bewys daarvan dat die grondliggende ooreenkoms (causa) en die bedoeling om eiendomsreg oor te dra in die na-klassieke tyd van mekaar losgemaak is, word gevind in die kommentaar van Konstantyn

86 Fuchs lusta Causa 17-19; Molkenteller Dinglichen Vertrag 71-72; Honsell Römisches Recht 156 vn 8.

87 Die Basilica was 'n negende eeuse Griekse verwerking van die Corpus luris Civilis deur keiser Leo die Wyse vir die Oos-Romeinse ryk. Vanaf 1350 is die Hexabiblos, 'n uittreksel uit die Basilica, in die praktyk gebruik. Sien Lokin Leerstukken 36.

88 Wat handel oor die geval waar die oordraggewer van oordeel is dat hy geld skenk, maar die verkryger dink dat dit aan hom geleen word.

89 Fuchs Iusta Causa 19; Molkenteller Dinglichen Vertrag 72-73; Honsell Römisches Recht 160 (mvn Scheltema Basilicorum Libri 1539 no 1). 
Nikaios ('n juris uit die elfde eeu) op Digesta 12.1.18 en Basilica 23.1.18. ${ }^{90}$ In ooreenstemming met die klem wat daar in hierdie tydperk op die bedoeling van die partye geplaas word, leer Nikaios dat eiendomsreg oorgaan indien fisiese beheer verskaf word met die wedersydse bedoeling (wilsooreenstemming) om eiendomsreg oor te dra en te ontvang. Die feit dat die grondliggende ooreenkoms agterna blyk nietig te wees omdat die partye byvoorbeeld gedwaal het, het geen invloed op die oorgang van eiendomsreg nie. ${ }^{91}$ Die deurslaggewende vraag is of die partye op die oomblik waarop fisiese beheer verskaf word, die bedoeling gehad het om eiendomsreg oor te dra en dit kan die geval wees selfs al is die causa nie geldig nie. Die bedoeling om eiendomsreg oor te dra wat ten tyde van sluiting van die verbintenisskeppende ooreenkoms bestaan het, word nie deur die nietigheid van die causa beïnvloed nie; dit bly afsonderlik voortbestaan. Die wedersydse bedoeling (wilsooreenstemming) om eiendomsreg oor te dra, is egter nog nie deur Nikaios ten volle van die causa losgemaak nie, aangesien dit steeds verwys het na die bedoeling soos wat dit in die causa (kousale ooreenkoms) vervat is. Ook hy het dus nog nie 'n selfstandige saaklike ooreenkoms in gedagte gehad nie. ${ }^{92}$

Die bespreking hierbo het aan die lig gebring dat alhoewel die bedoeling om eiendomsreg oor te dra en te ontvang in die tyd van Justinianus en die eeue daarna al hoe meer beklemtoon is, die bedoeling nog nie van die causa losgemaak is nie; dit was in die causa vervat. ${ }^{93}$ Dit het dus nog nie ' $n$ selfstandige bestaan onafhanklik van die causa gevoer nie. Een van die kenmerke van 'n abstrakte stelsel (naamlik die inhoudelike abstraksie) het dus

90 Raadpleeg Fuchs Iusta Causa 22-26; Honsell Römisches Recht 160; Molkenteller Dinglichen Vertrag 73 (mvn Scheltema Basilicorum Libri 1539 no 4).

91 In effek gee hy dus voorkeur aan Julianus se standpunt soos in Digesta 41.1 .36 (Basilica 50.1.36) vervat.

92 Molkenteller Dinglichen Vertrag 73-74; Fuchs Iusta Causa 24-25. Savigny wat van oordeel was dat 'n abstrakte oordragstelsel in die Justiniaanse reg toegepas is, het swaar op Nikaios se aantekening gesteun.

93 Die bedoeling waarvan in die tekste wat hierbo bespreek is melding gemaak word, verwys na die bedoeling wat ten tyde van sluiting van die kousale ooreenkoms (causa) bestaan het. 
ontbreek. ${ }^{94}$ Daar is nogtans tekens daarvan dat die bedoeling om eiendomsreg oor te dra algaande van die causa losgemaak is. ${ }^{95}$

\section{$7 \quad$ Vormvereistes - skrif en registrasie}

In die hedendaagse Suid-Afrikaanse reg word verbintenisskeppende ooreenkomste dikwels aan streng vormvereistes, waaronder skrif, onderwerp. Daarbenewens word vir die oordrag van eiendomsreg in onroerende goed vereis dat ' $n$ transportakte in die akteskantoor geregistreer word. Die vraag is nou wat die posisie in die Romeinse reg was?

Justinianus het die vormvoorskrifte by die oordrag van eiendomsreg op onroerende goed wat in die vulgêre reg na vore gekom het, gehandhaaf. Hierdie bepalings was van 'n fiskale aard en het ten doel gehad om grondbelasting in te vorder. ${ }^{96}$ Novellae 17.8 .1 het die verkoper verplig om skriftelik borg te staan vir die betaling van grondbelasting indien die koper armlastig was. Ingevolge Novellae 167 moes die verkryger van onroerende goed 'n skriftelike verklaring aflê waarin verklaar word dat iemand anders nie fisies in beheer van die grond is nie. ${ }^{97}$ Daarbenewens moes daar ook skriftelike getuienis voorsien word deur landbouers en rentmeesters dat hulle die nuwe eienaar ken. Anders as in die vulgêre reg, was skrif nie 'n voorvereiste in geval van die koop of ruil van grond nie. Die partye het 'n keuse gehad of hulle die kontrak op skrif wou stel, al dan nie. ${ }^{98}$ Dit wil dus voorkom of die geldigheid van die regshandeling en oordrag van eiendomsreg nie van skrif afhanklik was nie en dat skrif bloot die doel gedien het om bewys te vergemaklik. Skrif is wel vir skenkings voorgeskryf. Daarbenewens moes die skenking by die stedelike, provinsiale of geestelike gesagsdraer aangemeld word en moes die

94 Levy Vulgar Law 155; Molkenteller Dinglichen Vertrag 71 74; Baus Kausale Verfügung 32; Lange Kausale Element 15-16.

95 Honsell Römisches Recht 159-160.

96 Kaser Privatrecht II 74.

97 Lokin Overdracht 20-21.

98 Justinianus het mondelinge kontrakte uitdruklik erken. Sien Codex 4.12.17 pr; Institutiones 3.23 pr; Levy Vulgar Law 150, 152 ev; Kaser Privatrecht II 77-78; Kaser/Wubbe Romeins Privaatrecht 19-20. 
skenkingsakte geregistreer word. ${ }^{99}$ In die akte moes uitdruklik daarvan melding gemaak word dat fisiese beheer oorgedra is. Vir hierdie doel is ' $n$ grondregister ontwerp wat deur owerheidsamptenare bygehou is. ${ }^{100}$ Indien regshandelinge vir enige doel op skrif gestel is, moes die dokument aan die volgende vormvoorskrifte voldoen: ${ }^{101}$ die dokument moes deur die partye onderteken word (subscriptio); indien 'n tabellio meegewerk het, moes hy die dokument voltooi (complere) deur sy onderskeidende merk op die dokument aan te bring en dit te onderteken; die partye moes dit goedkeur (absolvere); die dokument moes dateer word en deur getuies onderteken word. ${ }^{102}$ Dit moet weer beklemtoon word dat traditio per cartam nie in die Justiniaanse reg 'n regtens erkende wyse van oordrag was nie. Possessio (en eiendomsreg) kon dus nie deur 'n skriftelike akte oorgedra word nie, die verkryger moes werklik fisies in beheer van die saak geplaas word. ${ }^{103}$

\section{$8 \quad$ Samevatting}

1. In die tyd van Justinianus verwys die begrip possessio na fisiese beheer oor 'n saak met die animus dominus - dit wil sê, die bedoeling om fisiese beheer as eienaar uit te oefen (wat van die klassieke animus possidendi onderskei moet word). ' $n$ Verdere ontwikkeling is die feit dat daar al hoe meer klem geplaas word op die animus-element wat nou as die wesenskenmerk van possessio gesien word (en nie corpus nie). Hierdie vergeesteliking van possessio het tot gevolg gehad dat dit van fisiese beheer losgemaak is. ${ }^{104}$

99 Die skenking moes egter net geregistreer word indien die waarde daarvan meer as 300 (later 500) solidi was. Institutiones 2.7.2.

100 Alhoewel registrasie nie in geval van koop voorgeskryf is nie, was dit nogtans gebruiklik om die oordrag van grond in munisipale registers te registreer. Levy Vulgar Law 150, 152; Lokin Overdracht 21; Delport Lewering en Registrasie 122-123; Kaser Privatrecht II 77-78, 81. Hierdie vorm van registrasie kan nie aan die hedendaagse praktyk waarvolgens 'n transportakte in die akteskantoor geregistreer word, gelyk gestel word nie.

101 Sien Codex 4.21.17 (528nC).

102 Kaser Privatrecht II 78-79.

103 Levy Vulgar Law 153-154.

104 Hierdie ontwikkeling is onverklaarbaar as in gedagte gehou word dat Justinianus juis die feitlike aard van possessio beklemtoon het. 
2. Die feit dat possessio nie meer noodwendig met fisiese beheer gepaard gegaan het nie, het daartoe meegewerk dat dit nader aan 'n eiesoortige reg gekom het as wat in die klassieke reg die geval was. Possessio is dus nie meer bloot 'n feitlike toestand nie; dit verkry die kenmerke van 'n reg. Die gevolg hiervan was weer dat die onderskeid tussen dominium en possessio nie duidelik was nie.

3. Alhoewel possessio in die tyd van Justinianus al hoe meer losgemaak is van werklike fisiese beheer oor 'n saak, was een of ander vorm van fisiese kontak, hoe gering ook al, steeds in beginsel 'n vereiste vir die oordrag van eiendomsreg. Daar is slegs in uitsonderlike gevalle van hierdie vereiste afgesien. Die implikasie is dat eiendomsreg in beginsel nie deur blote ooreenkoms oorgegaan het nie, die saak moes gelewer word. ${ }^{105}$

4. Anders as wat in die vulgêre reg die geval was, vind oordrag van eiendomsreg ten opsigte van roerende en onroerende goed nie meer direk deur die koop of skenking (blote ooreenkoms) plaas nie, maar wel deur die verskaffing van fisiese beheer op grond van 'n causa. Daar word dus weer duidelik onderskei tussen die causa (verbintenisskeppende ooreenkoms wat tot oordrag verplig) en verskaffing van fisiese beheer (traditio in die eng sin).

5. Daar bestaan geen duidelikheid oor die vraag of die stelsel in die tyd van Justinianus kousaal dan wel abstrak was nie. Daar kan steun vir beide stelsels in die tekste aangetref word. In gevalle waar oordrag uit hoofde van koop of skenking plaasgevind het, het nietigheid van die voorafgaande causa ook verhinder dat eiendomsreg oorgaan. Lewering moes op grond van 'n objektief geldige causa plaasvind. In hierdie gevalle was die stelsel kousaal en het dit dus nie kenmerke van 'n uitwendige abstraksie vertoon nie. In gevalle waar oordrag plaasgevind het op grond van 'n bruidskat, mutuum of solutio uit hoofde van 'n stipulatio, was oordrag egter nie van 'n geldige causa afhanklik nie. Oordrag het slegs uit 'n leweringshandeling waardeur die verkryger fisies in beheer gestel is, bestaan. Eiendomsreg het slegs oorgegaan, indien 
die vervreemder bedoel het om eiendomsreg oor te dra en die verkryger bedoel om eiendomsreg te ontvang. In hierdie opsig kan daar dus wel kenmerke van 'n uitwendige abstraksie bespeur word.

6. Daar is talle aanduidings daarvan dat daar in die tyd van Justinianus al hoe meer klem op die bedoeling om eiendomsreg oor te dra en te ontvang geplaas word. Behalwe in geval van mutuum en solutio, was dit egter steeds die bedoeling ten tyde van sluiting van die kousale ooreenkoms wat ter sprake was (traditio was dus steeds van die causa afhanklik). Daar was in die Justiniaanse reg dus nog geen sprake daarvan dat die bedoeling van die verbintenisskeppende ooreenkoms of causa losgemaak is en ' $n$ selfstandige bestaan gevoer het nie.

7. Daar is nietemin aanduidings daarvan dat die bedoeling in die tydperk na Justinianus tot die elfde eeu, geleidelik losgemaak word van die causa. Daar word byvoorbeeld ingesien dat die bedoeling om eiendomsreg oor te dra (soos vervat in die causa) kan bly voortbestaan selfs al is die causa nietig. Die ketting is egter nog nie finaal gebreek nie, omdat daar nog geen sprake is van 'n selfstandige oordragsbedoeling wat onafhanklik van die grondliggende ooreenkoms (causa) funksioneer nie. $^{106}$

8. Oor die algemeen was skrif nie 'n vereiste vir die geldigheid van die verbintenisskeppende ooreenkoms (causa) soos koop of ruil nie. Skrif is slegs in geval van skenkings regtens voorgeskryf. Dit was nogtans gebruiklik om ook koop en ruilkontrakte op skrif te stel.

9. Registrasie is regtens voorgeskryf vir die skenking van waardevolle sake, soos byvoorbeeld grond. Dit het tot gevolg gehad dat munisipale grondregisters tot stand gekom het wat deur owerheidsamptenare in stand gehou is. Alhoewel registrasie nie vir koop of ruil voorgeskryf is nie, was dit nogtans die praktyk om koop en ruilkontrakte wat op die vervreemding van grond betrekking gehad het in die registers te registreer. Dit is nie net die kontrak wat geregistreer is nie, ook die feit dat lewering plaasgevind het (dat eiendomsreg oorgegaan het), is

106 Kaser Privatrecht II 283; Lange Kausale Element 98; Molkenteller Dinglichen Vertrag 7475; Lokin Overdracht 20. 
geregistreer. Registrasie was egter geen konstitutiewe vereiste vir die oordrag van eiendomsreg nie en kan ook nie met die hedendaagse aktespraktyk vereenselwig word nie. Een van die belangrikste verskille, is dat die verbintenisskeppende ooreenkoms geregistreer is en nie ' $n$ transportakte nie. In die lig van die bespreking in hierdie artikel behoort dit ook duidelik te wees dat geen kenmerke van die inhoudelike of uitwendige abstraksie in die betrokke dokumente aangetref is nie.

10. In die oordragsproses kon hoogstens twee handelinge onderskei word, naamlik: (1) die causa en (2) traditio (wat bestaan het uit 'n fisiese en 'n geestelike element). Die wedersydse bedoeling om eiendomsreg oor te dra en te ontvang het nie onafhanklik van die verbintenisskeppende regsfeit bestaan nie en is ook nie as ' $n$ selfstandige ooreenkoms wat bloot deur wilsooreenstemming tot stand kom gekonstrueer nie. Vir sover as wat die bedoeling wel ' $n$ rol gespeel het, was dit die bedoeling wat implisiet in die kousale ooreenkoms opgesluit is wat ter sprake gekom het. Een van die onderskeidende kenmerke (essentialia) van die saaklike ooreenkoms - inhoudelike abstraksie - het dus ontbreek. 'n Ander onderskeidende kenmerk van die saaklike ooreenkoms, naamlik die uitwendige abstraksie, is wel in 'n beperkte omvang aangetref, maar daar is ook gevalle waar dit nie van toepassing was nie. Die gevolgtrekking is dat daar in die Romeinse reg nog geen sprake van ' $n$ saaklike ooreenkoms was nie. Hierdie konstruksie was vir die praktiese Romeinse juriste te kunsmatig en abstrak. Die siening van Nikaios kan nietemin gesien word as die eerste tree in die ontwikkeling van ' $n$ selfstandige saaklike ooreenkoms wat slegs bestaan uit die wedersydse bedoeling om eiendomsreg oor te dra wat op wilsooreenstemming gegrond is. 


\section{Bibliografie}

Baus Kausale Verfügung

Baus G Kausale Verfügung und gutglaubiger Erwerb (F Vahlen Berlyn 1939)

Carey Miller Acquisition

Carey Miller DL The Acquisition and Protection of Ownership (Juta Kaapstad 1986)

Codex Iustinianus

Krüger P (red) Corpus Iuris Civilis Vol II $9^{\mathrm{e}}$ uitg (Weidmann Berlyn 1915)

Delport Lewering en Registrasie

Delport JT Lewering en Registrasie as Eiendomsoordragshandelinge in die Suid-Afrikaanse Reg (LL D-proefskrif Universiteit van Port Elizabeth 1976)

Digesta Iustiniani

Spruit JE, Feenstra R en Bongenaar KEM (reds) Corpus luris Civilis Vol IIVI (Walburg Pers Zutphen 1993-2001)

Dondorp en Schrage Levering

Dondorp JH en Schrage EJH Levering Krachtens Geldige Titel: Enige Grepen uit de Geschiedenis van de Vereisten Voor Eigendomsoverdracht (VU Uitgewers Amsterdam 1991)

\section{Ehrhardt Iusta Causa}

Ehrhardt A Iusta Causa Traditionis: Eine Untersuchung Über den Erwerb des Eigentums nach Römischem Recht (De Gruyter Berlyn 1930)

Feenstra (red) Grondslagen

Feenstra R (red) Romeinsrechtelijke Grondslagen van het Nederlands Privaatrecht $5^{\mathrm{e}}$ uitg (Brill Akademiese Uitgewers Leiden 1990) 
Fuchs lusta Causa

Fuchs JG Iusta Causa Traditionis in der Romanistischen Wissenschaft

(Helbing \& Lichtenhahn Basel 1952)

Gordon Traditio

Gordon WM Studies in the Transfer of Property by Traditio (Universiteit van Aberdeen Aberdeen 1970)

Hazewinkel-Zuringa D Mancipatio en Traditio Bijdrage tot de Kennis van de Eigendomsoverdracht in het Romeinsche Recht (Proefskrif Universiteit Amsterdam 1931)

Honsell, Mayer-Maly en Selb Römisches Recht

Honsell H, Mayer-Maly T en Selb W Römisches Recht $4^{\mathrm{e}}$ uitg (Springer Berlyn 1987)

Institutiones Iustiniani

Krüger P (red) Corpus luris Civilis Vol I $21^{\mathrm{e}}$ uitg (Weidmann Berlyn 1970)

\section{Kaser Privatrecht}

Kaser M Das Römische Privatrecht Band I \& // 2e uitg (Beck München 1971-1975)

KaserMubbe Romeins Privaatrecht

Kaser M Das Römische Privatrecht (Nederlandse vertaling van die oorspronklike Duits deur Wubbe FBJ Romeins Privaatrecht) $2^{\mathrm{e}}$ uitg (Tjeenk Willink Zwolle 1971)

Kop Vulgaire Recht

Kop PC Beschouwingen over het zogenaamde 'Vulgaire' Romeinse Recht (Leiden Zwolle 1980) 


\section{Lange Kausale Element}

Lange H Das kausale Element im Tatbestand der klassischen Eigentumstradition (Weicher Leipzig 1930)

Levy Vulgar Law

Levy E West-Roman Vulgar Law: The law of Property (American Philosophical Association Philadelphia 1951)

Lokin Leerstukken

Lokin JHA Vermogensrechtelijke Leerstukken Aan de Hand van Romeinsrechtelijke Teksten (Rijksuniversiteit Gröningen 1991)

\section{Lokin Overdracht 9-21}

Lokin JHA "De overdracht van onroerend goed in het Romeinse recht" in Ars No-tariatus XXXII De levering van onroerend goed. Vijf opstellen over de over-dracht van onroerend goed vanaf het Romeinse recht tot het Nieuw Burgerlijk Wetboek (Kluwer Deventer 1985)

Middelberg Houderschap Middelberg AWF Bescherming van het Houderschap (LL D-proefskrif Universiteit van Pretoria 1953)

Molkenteller Dinglichen Vertrag Molkenteller DH Die These vom Dinglichen Vertrag: Zur Formalen Struktur der Eigentumsübertragung nach $\$ 929$ Satz 1 BGB (Peter Lang Frankfurt 1991)

Novellae lustiniani

Scholl L en Kroll W (reds) Corpus Iuris Civilis Vol III (Berlyn 1895)

Pringsheim 1933 LQR 43-60

Pringsheim F "Animus in Roman Law" 1933 The Law Quarterly Review 4360 
Van der Walt Houerskap

Van der Walt AJ Ontwikkeling van Houerskap (LL D-proefskrif

Potchefstroomse Universiteit vir Christelike Hoër Onderwys 1985)

Van Oven Bezitsbescherming

Van Oven JC De Bezitsbescherming en Hare Functies (Proefskrif Universiteit van Amsterdam 1905)

Van Oven JC Romeinsch Privaatrecht

Van Oven JC Leerboek van Romeinsch Privaatrecht $3^{\mathrm{e}}$ uitg (Brill Akademiese Uitgewers Leiden 1948)

Van Zyl DH Romeinse Privaatreg

Van Zyl DH Geskiedenis en Beginsels van die Romeinse Privaatreg $2^{\mathrm{e}}$ uitg (Butterworths Durban 1977)

Voß Recht und Rhetorik

Voß WE Recht und Rhetorik in den Kaisergesetzen der Spätantike (Loewenklau Gesellschaft Frankfurt 1982)

Weiss Institutionen

Weiss E Institutionen des Römischen Privatrechts $2^{\mathrm{e}}$ uitg (J Hess Stuttgart 1949)

Zimmermann Obligation

Zimmermann R The Law of Obligations: Roman Foundations of the Civilian Tradition (Juta Kaapstad 1990)

\section{Register van hofsake}

Air-Kel (Edms) Bpk h/a Merkel Motors v Bodenstein en 'n ander 19803 SA 912

(A)

Bank Windhoek v Rajie 19941 SA 115 (A)

Cape Explosive Works Ltd and another v Denel (Pty) Ltd and others 20013 SA 569 (HHA) 577-578 
Commissioner of Customs and Excise $v$ Randles, Brothers and Hudson Ltd 1941 AD 369

Concor Construction (Cape) (Pty) Ltd v Santambank 19933 SA 930 (A)

Dryer NO and another v AXZS Industries (Pty) Ltd 2005 JOL 15566 (HHA) KrapohI v Oranje Koöperasie Bpk 19903 SA 848 (A)

\section{Register van Internet bronne}

Schutte 2000 PER 4-6 http://www.puk.ac.za/ 30 Mei

Schutte PJW "Oordrag van Eiendomsreg in die Vulgêre reg in die Wes-

Romeinse ryk" 2000 (2) Potchefstroomse Elektroniese Regsblad

[Beskikbaar op internet]

http://www.puk.ac.za/fakulteite/regte/per/issue00v2.html [Datum van gebruik 30 Mei 2007] 